\title{
Establishment of the carbon label mechanism of coal chemical products based oncarbon footprint
}

\author{
Wu Bishan"; Liu Zhenling ${ }^{2 *}$, Muhammad Aqeel Ashraf ${ }^{3}$. \\ ${ }^{1}$ Langfang Teachers University, Hebei, 065000, China Email:wubishan1024@sina.com; ${ }^{2}$ School of Management, \\ Henan University of Technology, Zhengzhou, 450001, Henan; ${ }^{3}$ Faculty of Science and Natural Resources, \\ University Malaysia Sabah 88400, Kota Kinabalu, Sabah, Malaysia.
}

\begin{abstract}
After redefining the carbon footprint and carbon label, the paper analyzesthe significance of the carbon labels under the background of the low carbon economy development, and establishes the concept of model of the carbon labels mechanism to chemical products. At the same time, the paper quantitatively studies carbon label data sourceof three kinds of coal chemical industry power products, which are fromhaving not CCS technologies of supercritical boiler of coal, using CCS technologies of supercritical boiler of coal and adopting CCS and IGCC technologies to power generation in CCI. Based on the three kinds of differences, the paper puts forward of establishing the carbon labels mechanism of chemical products under the low carbon consumption.
\end{abstract}

Keyword: carbon label, carbon footprint, coal chemical industry, carbon capture and storage

\footnotetext{
*Authors for correspondence: liuzhenlong1858@126.com
} 


\section{INTRODUCTION}

Carbon Label (CL) wasthe earliest put forward by the BSI in British based on PAS2050 standard ${ }^{[1]}$, as a method to assess the intensity of Carbon Footprint $(\mathrm{CF})$ of products in the whole life cycle. In 2011, the more specific criterion and specification are given to the productsfrom PAS2050 for CF assessment. Many countries or regions in the world are beginning to set up lowcarbon certification system to their own products. Intensity of CF can be quantitatively calculatedby the emission volume of Green House Gas (GHG). $\mathrm{CL}$ of the products is a kind of ecological labels, which can provide information to consumers to make them understand the direct or indirect release amount of GHG from the purchased products throughout the life cycle ${ }^{[2-6]}$. Manufacturing located in the upstream of the supply chain are also increasingly feel the trend and the influence of pressure. Some suppliers are being told to need to account carbon emissions and provide material consumptions of a business or a product, such as energy consumption data. With government policy and market mechanism, $\mathrm{CF}$ standardwill become one of the environmental managing goals and means to the products in the future.

As a kind of management mechanism in the low carbon economy, the system of CL must have several most basic expanding elements. The first is that the $\mathrm{CF}$ database of product is established to accurately measuring $\mathrm{CF}$ and identifying the $\mathrm{CF}$ data of productsin life cycle.So, the downstream consumers or the demand enterprises can understand the information of $\mathrm{C}$ element from the material flow in the products. The second is the technical requirements of CL used, such as data read, writing, type, designing technology, etc. The third is the adapting objects and scope of CL.The fourth is how to establish a standard management mechanism of CL. Establishing evaluation index of CL to the different industries, the different types of products, downstream demand or consumers will consciously practice the purchasing reference standard in the green consumption, such as the CL from Chinese Taiwan is shown in figure 1 .

\section{Fig1. The carbon label of Taiwan in China}

As the similar connotation of CL in Taiwan to accurately inform consumers about accounting information of $\mathrm{CF}$ from their products, Levi, who is international famous brand of the jeans maker with $\mathrm{CL}$ on its hundreds of product: the $\mathrm{CO}_{2 \text {-e }}$ (Carbon Dioxide Equivalent) of the product in its life cycle, $32.3 \mathrm{~kg}$ of carbon emission. The volume of the carbon emissions is equivalent to six tree to absorbent $\mathrm{CO}_{2}$ in a year.Again, such as, some TV makers tell consumers by $\mathrm{CL}$ on their own products: watching $\mathrm{TV}$ in one hour, which will emit $0.2 \mathrm{~kg}$ of $\mathrm{CO}_{2-\mathrm{e}}$. Some abroad service providers are also suggesting consumers with $\mathrm{CL}$, each passenger by plane travel $1000 \mathrm{~km}$, will emit about $170 \mathrm{~kg}$ of $\mathrm{CO}_{2-\mathrm{e}}^{\text {[7] }}$.

With the matures rules of global carbon tax and carbon market, ISO and other international organizations continually introduce the low carbon standard, the similar normative documents, such as PAS2050. Some technical requirements of CL and evaluation system are becoming more complete. When compulsory certification technology and standards are becoming mature, $\mathrm{CL}$ of products $\mathrm{f}$ will be as threshold of market access to procurement and sales of various products. While production enterprises in the transition come from voluntary emissions reduction to be mandatory cutting objects, CL will undoubtedly become a "green traffic permit" for products into the domestic and international market, which are also the tools of the trade protectionism by some developed countries to tryto be the political game mastersin low carbon economy. Therefore, the connotation of CLhas exceed the original meaning of low carbon economy development ${ }^{[8-9]}$.

With the CF information accurately informing downstream consumers in the every link of life cycle of the products, producers or sellers of Coal Chemical Industry (CCI) products use CL quantitative marked on the products packaging. At the same time, $\mathrm{CL}$ is an implementation tool to some countries in low carbon economic development, which is o one of the means of international trade barriers to avoid low carbon technology. So that, every government is actively organizing relevant organizations to establish or research theregulatory mechanism of CL of CCI products with low-carbon development ${ }^{[10]}$.

\section{Establishing conceptual model of CL on CCI products}

In whole life cycle, coal mining, logistics, chemical conversion, consumption, each link of CCI products has many GHG emission source. The volume of $\mathrm{CO}_{2-\mathrm{e}}$ of each piece of $\mathrm{CCI}$ productsis the sum total of all GHG emissions of emissions sources within each subsystem, which is 
also the measurement values of $\mathrm{CF}$ strength identified by the product CL on products to inform downstream consumers. Inspired by the carbon tax effect on consumption, consumers would rationally choose $\mathrm{CCI}$ products in low carbon according to the number of $\mathrm{CF}$ on $\mathrm{CL}_{\circ}$ Based on LCA, the accounting methods CF from subsystems, carbon tax and carbon trading management mechanism, the paper establishes concept model of CL on CCI products, which is shown in Figue2.

Fig2. The concept model of the carbon label on the CCI products

With the aboveanalysis of the CCI concept model of $\mathrm{CL}$ on CCI products, the related production enterprise in CCI must product the products with lowercarbon emissions by the use of CCI clean technology in multi-industrial clusters. So, the CCI enterprises must try to make own products with CL accordance with access standards of domestic and international market, and enhance the competitiveness of the products with CL.

In the new type industrial chain of core CCI, such as coal gasification- $\mathrm{CH}_{3} \mathrm{OH}-\mathrm{IGCC}$, coal gasification -SNG (Synthetic Natural Gas)-IGCC (Integrated Gasification Combined Cycle) and direct coal liquefaction- indirect coal liquefaction, will manufacture a large number of chemical products and parts of secondary energy. Among them, the SNG, $\mathrm{CH}_{3} \mathrm{OH}, \mathrm{MTO} / \mathrm{MTP}, \mathrm{PVC}, \mathrm{DEM}$, chemical fertilizers, acetic acid, electric power, oil and other products are industrialnecessities. Opposite to traditional CCI process, these products have the advantage of lowercarbon emissions, but products are after all based on coal, which have a lot of GHG emissions with consumption process.

Therefore, the strength of CF on CCI products can be identified by $\mathrm{CL}$, which can be as low carbon consumption to downstream consumers. For example, industrial enterprises or residents in purchasing power compare the produce and consumption per kilowatt-hour, directly or indirectly, emissions of $\mathrm{CO}_{2-\mathrm{e}}$ by observing the $\mathrm{CF}$ numbers on electric productswith CL. Especially,after the government begin to levy carbon tax to power consumers, the power consumers have to measure problems, such as environmental pollution and costs, eventually choosing supercritical coal-fired power or rational electric by CCS (Carbon Capture and Storage) technology or IGCC (Integrated Gasification Combined Cycle) power.

\section{Examples of simulation}

After using the clean technologies, such as CCS, CCI enterprisesbegin to have relatively lower GHG emissions. At the same time, these CCI enterprisescan also enjoy policy subsidies from the government for using low carbon technologies. Especially,after registering as CDM (Clean Development Mechanism) project members, some CCI enterprises can also sell CERs (Certified Emission Reduction) permits to gain more benefits in the carbon market. Among them, some CCI enterprises, which integrate with the technologies of CCS or IGCC,do not only enjoy the reform dividend in the clean development mechanism (CDM), but also its downstream consumers can enjoy high quality life for low carbon economy, such as the consumers using electric powerwith IGCC.

Assuming that an electric power industry city, A, there are three kinds of power source suppliers with different power generations: one does not use CCS technologies of coal supercritical boiler, the second is using the CCS technology of coal supercritical boiler, the third is using CCS technology of CCI gasification combined with IGCC, which is shown in Figue3.

\section{Fig3. The three types of the electric power} between supply and demand in one area

Above the diagram, the first kind of power enterprisesin A city, which rely on supercritical boilers supply electricity without the clean technologiessuch as CCS or not registering as $\mathrm{CDM}$ project members, belong to the traditional coal enterprises in China.The second kind of power enterprisesin A city, which rely on supercritical boilers supply electricity with the clean technologiessuch as CCS and registering as $\mathrm{CDM}$ project members. The third kind of power enterprisesin A city, which rely on the CCI integrating IGCC power generation with the circular economy mode, and use the clean technologies with CCS, and registering as CDM project members.

Due to adopt clean technologies such as CCS or IGCC based on CCI or members of the registering CDM projects, the three kinds of electric power enterprises have different waysto the production of electric power, and the cost of one KWH will be different. In addition, the electric power 
enterprises are also gradually turning to the new production modes for the government begins to levy a tax on carbon emissions, to enjoy policy subsidies for using clean technologies such as CCS or IGCC in CCI and becoming members of CDM projects. At the same time, the downstream consumers (industrial, urban residents) will choose power suppliers according to CL of electric power.

\section{The cost measurement of electric power enterprises with CCS technology}

The above analysis, the CCS technology used in CCI will go through the process: $\mathrm{CO}_{2}$ captured, transportation, storage, monitoring management. The every link needs cost. The accounting method of the unit cost of CCS can be operated ${ }^{[11-12]}$ :

$$
\mathrm{C}_{\mathrm{CCS}}=\quad \mathrm{C}_{\mathrm{CCS}-\mathrm{C}}+\mathrm{C}_{\mathrm{CCS}-\mathrm{Y}}+\mathrm{C}_{\mathrm{CCS}-\mathrm{F}}+\mathrm{C}_{\mathrm{CCS}-\mathrm{J}}
$$

Of which: $\mathrm{C}_{\mathrm{CCS}}$ represents the cost of using CCS in $\mathrm{CCI}, \mathrm{RMB} / \mathrm{tCO}_{2} ; \mathrm{C}_{\mathrm{CCS}-\mathrm{C}}$ represents the unit cost of capturing $\mathrm{CO}_{2}, \mathrm{RMB} / \mathrm{tCO}_{2} ; \mathrm{C}_{\mathrm{CCS} \text {-Y }}$ represents the unit cost of transporting $\mathrm{CO}_{2}, \mathrm{RMB} / \mathrm{tCO}_{2} ; \mathrm{C}_{\mathrm{CCS}-\mathrm{F}}$ represents the unit cost of $\mathrm{CO}_{2}$ storage, $\mathrm{RMB} / \mathrm{tCO}_{2} ; \mathrm{C}_{\text {CCS-J }}$ represents the unit cost of $\mathrm{CO}_{2}$ monitoring management, $\mathrm{RMB} / \mathrm{tCO}_{2}$. Reference to the above calculation formula and the international mature CCS, the paper can refer to the unit costs of CCS in CCI in China, are shown in table ${ }^{[13]}$.

Table1 - The costs of the CCS technology in CCI in China

\begin{tabular}{ll}
\hline $\begin{array}{l}\text { cost items of } \\
\text { CCS in CCI }\end{array}$ & $\begin{array}{l}\text { Costs } \\
\left(\mathrm{RMB} / \mathrm{tCO}_{2}\right)\end{array}$ \\
\hline $\begin{array}{l}\text { unit cost of } \\
\text { capturing }\end{array}$ & $93-465$ \\
unit cost of & $3.1-49.6$ \\
transporting & \\
unit cost of & $0.62-49.6$ \\
storage \\
unit cost of & $0.62-1.86$ \\
monitoring \\
total & $97.34-566.06$ \\
\hline
\end{tabular}

In A city, whether the three kinds of power production enterprises use CCS, which will haveobvious influencing to the total operating costs. The first kind of power production enterprises without using CCS technology only have its current production costs, logistics cost. The second and the third type of power production enterprises are using CCS or IGCC technologieswith the current operating costs, logistics management costs and $\mathrm{C}_{\mathrm{CCS}}$. In this paper, in order to the convenient study, the value of $\mathrm{C}_{\mathrm{CCS}}$ is gave, the averagedRMB0.202/tCO . In addition, the unit cost of production management and logistics management can consult relevant literatures ${ }^{[14-15]}$. Among them, the third type electric power enterprisesarethe new type CCI enterprises, which integrate IGCC power technologies. The $\mathrm{CO}_{2}$ capturedcomes from the subsystems of coal production, coal gasification, coal logistics subsystem, and so on other emission sources.

Therefore, the unit operating cost of the third type of the electric power enterprises with $\mathrm{C}_{\mathrm{CCS}}$ or IGCC in CCI, which can be accounted for ${ }^{[16]}$ :

$$
\begin{aligned}
& \mathrm{C}_{\mathrm{E}-\mathrm{CCS}}=\mathrm{C}_{\mathrm{SC}}+\mathrm{C}_{\mathrm{L}}+\mathrm{C}_{\mathrm{CCS}} \times \mathrm{CF}_{\mathrm{C}} / \mathrm{Q}_{\mathrm{FD}} \\
& =\mathrm{C}_{\mathrm{SC}}+\mathrm{C}_{1}+\mathrm{C}_{\mathrm{CCS}} \times\left(\sum_{m} \mathrm{CF}_{\mathrm{m}}+\sum_{L} \mathrm{CF}_{\mathrm{L}}+\sum_{\mathrm{g}}\right.
\end{aligned}
$$

$\left.\mathrm{CF}_{\mathrm{g}}\right) \times \eta_{\mathrm{C}} / \mathrm{Q}_{\mathrm{FD}}$

Of which: $\mathrm{C}_{\mathrm{E}-\mathrm{CCS}}$ represents the unit operating cost of electric power enterprises with CCS, $\mathrm{RMB} / \mathrm{kwh} ; \mathrm{C}_{\mathrm{SC}}$ represents the unit production cost , RMB/kwh ; $\mathrm{C}_{\mathrm{L}}$ represents the unit logistics cost, $\mathrm{RMB} / \mathrm{kwh} ; \mathrm{CF}_{\mathrm{C}}$ represents the volume of $\mathrm{CO}_{2}$ captured, $\mathrm{tCO}_{2} / \mathrm{a} ; \eta_{\mathrm{C}}$ represents the efficiency of $\mathrm{CO}_{2}$ captured, \%; $\mathrm{Q}_{\mathrm{FD}}$ represents the electric energy production, $\mathrm{Mwh} / \mathrm{a} ; \sum_{\mathrm{m}} \mathrm{CF}_{\mathrm{m}}$ represents the volume of $\mathrm{CF}$ from coal mining, t $\mathrm{CO}_{2-\mathrm{e}} / \mathrm{a} ; \sum_{L} \mathrm{CF}_{\mathrm{L}}$ represents the volume of $\mathrm{CF}$ from coal logistics, $\mathrm{t}$ $\mathrm{CO}_{2-\mathrm{e}} / \mathrm{a} ; \sum_{g} \mathrm{CF}_{\mathrm{g}}$ represents the volume of $\mathrm{CF}$ from coal processing, $\mathrm{t} \mathrm{CO}_{2-\mathrm{e}} / \mathrm{a}$. The costs of $\mathrm{CCS}$ or IGCC in CCI impact on the operating costs of three kinds of power production enterprises in $\mathrm{A}$

\begin{tabular}{|c|c|c|c|c|c|c|}
\hline Cost items & $\begin{array}{l}\text { 1th } \\
\text { enterprises }\end{array}$ & power & $\begin{array}{l}2 \text { th } \\
\text { enterprises }\end{array}$ & power & $\begin{array}{l}\text { 3th } \\
\text { enterprises }\end{array}$ & power \\
\hline volume of $\mathrm{CO}_{2}$ captured, $\mathrm{t} / \mathrm{Mwh}$ & 0 & & 0.951 & & 0.859 & \\
\hline volume of $\mathrm{CO}_{2}$ emission, $\mathrm{t} / \mathrm{Mwh}$ & 0.797 & & 0.106 & & 0.095 & \\
\hline
\end{tabular}
city, are shown in table 2.

Table2. The costs of the electric power enterprises including CCS expenses 


$\begin{array}{llll}\begin{array}{l}\text { Product cost }+ \text { logistics } \\ \text { cost, } \mathrm{RMB} / \mathrm{kwh}\end{array} & 0.271 & 0.271 & 0.239 \\ \begin{array}{l}\text { unit cost of } \mathrm{CCS}, \mathrm{RMB} / \mathrm{tCO}_{2} \\ \text { operating costs with } \mathrm{CCS}, \mathrm{RMB} /\end{array} & 0.271 & 202 & 202 \\ \text { kwh } & & 0.463 & 0.413\end{array}$

From the above table, it can be seen to the unit minimum cost of electric power enterprises integrating IGCC in CCI without using CCS, which is less about $12 \%$ than the unit cost with supercritical coal-fired technologies. After using CCS capture technology, the volume of $\mathrm{CO}_{2}$ emissions reduces by $89 \%$ on average. This also reflects the result of studying the low-carbon technologies including CL mechanism. But, with CCS technology, the new investment, the operating costs of the electric power enterprises will increase, the average growth of around $70 \%$. This is also current embarrassing realm to many $\mathrm{CCI}$ enterprises. On the one hand, the governments try best to execute the clean development mechanism, on the other hand, this will bring huger pressureintothe operating costs of the electric power enterprises in CCI for using low carbon technologies.

\section{The influence to electric power costswith clean development mechanism}

Due to register as the members of CDM projects, the second and the third type of electric power enterprises can benefit from the carbon markets at home and abroad. The greater the amount of $\mathrm{CO} 2$ captured, the power enterprises will have the bigger benefits from carbon markets. The first kind of electric power enterprises without clean technologies, such as CCS or IGCC in CCI, who do not reduce $\mathrm{CO}_{2}$ emissions, are also impossible to gain more benefits in carbon markets by selling CERs permits.On the contrary, the second and the third type of electric power enterprises may gain more benefits from the CDM projects under the influence of the clean development mechanism by increasing investment. For CDM projectshave various types, and the CERs to carbon emissions is not regulated market in the world market price. The $\mathrm{CO}_{2}$ trading volume of carbon markets and transaction costs, prices standard are given in European Union, the United States and other countries and regions according to the annual $\mathrm{CO}_{2}$ indicators. But, relevant low-carbon policies and standards are in the process of planning and formulation such as CDM projects, carbon tax and carbon trading markets in China.These researches and implementation in China have just started. In order to protect domestic industry or the interests of the CCI enterprises, National Development and Reform Commission of China began to protocol the standards and pricesof CDM projects in 2012, which is shown in Table3.

Table3. The price standard of CDM projects in China

\begin{tabular}{lllll}
\hline CDM projects & CCI items & $\begin{array}{l}\text { Wind } \\
\text { electricity }\end{array}$ & $\begin{array}{l}\text { Reproducible } \\
\text { items }\end{array}$ & $\begin{array}{l}\text { Hydroelectric } \\
\text { items }\end{array}$ \\
\hline $\begin{array}{l}\text { Limited } \\
\text { price }\left(\text { Euro/ } / \mathrm{CO}_{2}\right)\end{array}$ & 8 & 10 & 10 & 12 \\
\hline
\end{tabular}

The electric power enterprises in A city basically adopt some production crafts in $\mathrm{CCI}$, the paper uses the region limit standard Euro8/tCO $\mathrm{tC}_{2}$ in $\mathrm{CDM}$ projects. According to the exchange rate of Euro and RMB on the day, 7.2:1, the respective unit costs can be calculated for:

$$
\begin{aligned}
\mathrm{C}_{\mathrm{E}-\mathrm{SQ}}= & \mathrm{C}_{\mathrm{E}-\mathrm{CCS}}-\mathrm{C}_{\mathrm{E}-\mathrm{CDM}} \times \mathrm{CF}_{\mathrm{C}} / \mathrm{Q}_{\mathrm{FD}} \\
& =\mathrm{C}_{\mathrm{SC}}+\mathrm{C}_{\mathrm{L}}+\left(\mathrm{C}_{\mathrm{CCS}}-\mathrm{C}_{\mathrm{D}-\mathrm{CDM}}\right) \times\left(\sum_{m} \mathrm{CF}_{\mathrm{m}}+\sum_{L}\right. \\
\left.\mathrm{CF}_{\mathrm{L}}+\sum_{g} \mathrm{CF}_{\mathrm{g}}\right) \times \eta_{\mathrm{C}} / \mathrm{Q}_{\mathrm{FD}} & (3)
\end{aligned}
$$

Of which: $\mathrm{C}_{\mathrm{E}-\mathrm{SQ}}$ represents the unit operating costs of electric power enterprises with CCS and CDM income, $\mathrm{RMB} / \mathrm{K}$ wh, which does not include the unit cost of the carbon tax; $\mathrm{C}_{\mathrm{E}-\mathrm{CDM}}$ represents the region limit standard of $\mathrm{CDM}$ projects, taking euro8/tCO $\mathrm{CO}_{2}$ in this paper, closed on RMB $57.6 / \mathrm{tCO}_{2}$. So, the operating costs of three kinds of electric power enterprise, which do not include carbon tax, are shown in Table4. 
Table 4. The costs of the electric power companies without carbon tax

\begin{tabular}{lllll}
\hline Cost items & $\begin{array}{l}\text { 1th } \\
\text { enterprises }\end{array}$ & $\begin{array}{l}\text { power } \\
\text { enterprises }\end{array}$ & $\begin{array}{l}\text { 2th } \\
\text { enterprises }\end{array}$ \\
\hline $\begin{array}{l}\text { volume of } \mathrm{CO}_{2} \text { captured, } \mathrm{t} / \mathrm{Mwh} \\
\text { volume of } \mathrm{CO}_{2} \text { emission, } \mathrm{t} / \mathrm{Mwh}\end{array}$ & 0.797 & 0.951 & 0.859 \\
$\begin{array}{l}\text { Operating cost with } \\
\mathrm{CCS}, \mathrm{RMB} / \mathrm{kwh}\end{array}$ & 0.271 & 0.106 & 0.095 \\
income of $\mathrm{CDM}, \mathrm{RMB} / \mathrm{tCO}_{2}$ & 0 & 0.463 & 0.413 \\
Costs of wiping off income of & 0.271 & & \\
$\mathrm{CDM}, \mathrm{RMB} / \mathrm{kwh}$ & & 0.055 & 0.050 \\
\end{tabular}

\section{Carbon tax on the influence of the costs of three} electric power enterprises

Unit operating costs of electric power enterprisesin A city will have different changes due to different volume of $\mathrm{CO}_{2}$ emissions after governments begin to levy carbon tax. The carbon tax is the product of the tax rate and the volume of carbon emissions. The volume of carbon emissions from electric power enterprises is higher so that they have the higher the carbon tax, which will increase the total costs of enterprises when government in A city unifies the carbon tax. That is to say, the carbon tax of the CCI enterprises will be affected for CCS and joining in CDM projects. In a period, the carbon tax rate is relatively stable in a country or a region. But the government will also adjust the proportion of carbon tax with specific situation of the economic changes. At the same time, some developed countries regard carbon tax as the tools of non-tariff trade barriers to the other developing countries.For example, since 2012, carbon tax rate is higher in some countries, which is shown in Table5.

Table 5.The different carbon-tax rate in the world in 2012

\begin{tabular}{llllllll}
\hline $\begin{array}{l}\text { cou } \\
\text { ntri }\end{array}$ & $\begin{array}{l}\text { Finl } \\
\text { and }\end{array}$ & $\begin{array}{l}\text { Ho } \\
\text { es }\end{array}$ & $\begin{array}{l}\text { Swe } \\
\text { nden }\end{array}$ & $\begin{array}{l}\text { Nor } \\
\text { sela } \\
\text { nd }\end{array}$ & $\begin{array}{l}\text { Bri } \\
\text { tai }\end{array}$ & Japan & $\begin{array}{l}\mathrm{Ca} \\
\text { nad } \\
\text { a }\end{array}$ \\
\hline car & 26.1 & 25 & 38.8 & $21 \$$ & 14 & 2400 & 30 \\
bo & $5 \$ / \mathrm{t}$ & $\$ / \mathrm{t}$ & $\$ / \mathrm{tC}$ & $/ \mathrm{tC}$ & $\$ / \mathrm{t}$ & $\mathrm{JPY} / \mathrm{t}$ & $\$ / \mathrm{t}$ \\
$\mathrm{n}-$ & $\mathrm{CO}_{2}$ & $\mathrm{CO}$ & $\mathrm{O}_{2}$ & $\mathrm{O}_{2}$ & $\mathrm{CO}$ & $\mathrm{CO}_{2}$ & $\mathrm{CO}$ \\
tax & & 2 & & & 2 & & 2 \\
rat & & & & & & & \\
e & & & & & & & \\
\hline
\end{tabular}

Since 2012, some large and medium-size CCI enterprises in China start to register CDM projects to actively join the carbon markets at home and abroad. After all, carbon tax brings operating pressure to $\mathrm{CCI}$ industry or small and mediumsized CCI enterprises at this stage in China. In order to steadily promote some mechanisms of low-carbon management, such as carbon tax, this paper argues that the government in China should implementthe carbon tax in stages to the CCI enterprises, and gradually levy carbon tax from low to high, which do not happen overnight to avoid causing short-term uncertain impacting on the microeconomic.

Therefore, when the government in A city levies carbon tax, the unit operating cost of electric power enterprises can be expressed for:

$$
\begin{aligned}
& \mathrm{C}_{\mathrm{E}-\mathrm{TS}}=\mathrm{C}_{\mathrm{E}-\mathrm{CCS}}-\mathrm{C}_{\mathrm{E}-\mathrm{CDM}} \times \mathrm{CF}_{\mathrm{C}} / \mathrm{Q}_{\mathrm{FD}}+\mathrm{CF}_{\mathrm{P}} \times \eta_{\mathrm{TS}} \\
& \quad=\mathrm{C}_{\mathrm{SC}}+\mathrm{C}_{\mathrm{L}}+\left(\mathrm{C}_{\mathrm{CCS}}-\mathrm{C}_{\mathrm{E}-\mathrm{CDM}}\right) \times\left(\sum_{m} \mathrm{CF}_{\mathrm{m}}+\sum_{L}\right. \\
& \left.\mathrm{CF}_{\mathrm{L}}+\sum_{g} \mathrm{CF}_{\mathrm{g}}\right) \times \eta_{\mathrm{C}} / \mathrm{Q}_{\mathrm{FD}} \\
& +\left(\sum_{m} \mathrm{CF}_{\mathrm{m}}+\sum_{L} \mathrm{CF}_{\mathrm{L}}+\sum_{g} \mathrm{CF}_{\mathrm{g}}\right) \times\left(1-\eta_{\mathrm{C}}\right) / \mathrm{Q}_{\mathrm{FD}} \times \eta_{\mathrm{TS}}
\end{aligned}
$$

(4)

Of which: $\mathrm{C}_{\mathrm{E}-\mathrm{TS}}$ represents the unit operating cost after levying carbon tax, $\mathrm{RMB} / \mathrm{kwh} ; \mathrm{CF}_{\mathrm{P}}$ represents the volume of $\mathrm{CO}_{2}$ emissions, $\mathrm{tCO}_{2} / \mathrm{a} ; \mathrm{H}_{\mathrm{TS}}$ represents the carbon tax rate, $\mathrm{RMB} / \mathrm{tCO}_{2}$. Using above calculation model, the unit operating cost accounting as a result for carbon tax to the different types of electric power enterprises in the A city, which is shown in Table 6. 
Table 6. The unit operating cost of the electric power enterprises including carbon tax

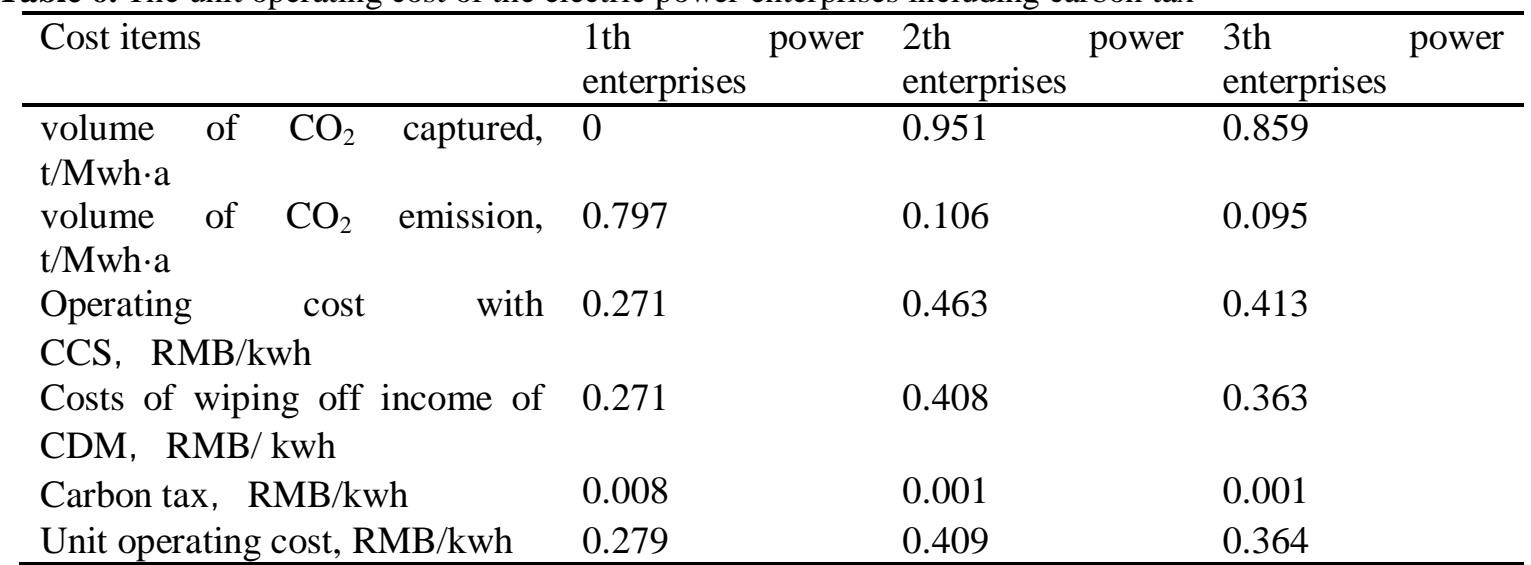

The influence of government subsidiesto theoperating cost for using CCS

Above preliminary calculation, the operating costs of electric power enterprises, which are in CCI with CCS or IGCC or becoming members of CDM projects, are much more than the first kind of supercritical coal-fired power generation enterprises without any reduction emissions in A city. The value of the second and the third type enterprises are respectively more $46.6 \%, 30.5 \%$ than the first. As a result, many coal enterprises in China, who are reluctant to increase the input in low-carbon technologies, still adopts traditional production mode of CCI. So, this paper argues that the government should begin to implement the clean development mechanism for CCI enterprises and give them policy subsidies, so that it makes CCI enterprises with low-carbon technologies can not only enjoy benefits from the CDM projects, but also gain greater competitiveness in the markets. If government gives full subsidies(for example, $\mathrm{RMB} 202 / \mathrm{t} \mathrm{CO}_{2-\mathrm{e}}$ ) for CCS in CCI under unifying the carbon tax rate, the second and the third type of electric power enterprises in A citywill reduce one ton $\mathrm{CO}_{2}$ emissions. So, operating fundamental change will occur to three kinds of power enterprises in A city. These results will be really realize the purposes of low-carbon industry development in CCI in China, which is shown in Table 7.

Table7. The costs of the electric power companies without CCS expenses by subsidies

\begin{tabular}{|c|c|c|c|}
\hline Cost items & $\begin{array}{l}\text { 1th power } \\
\text { enterprises }\end{array}$ & $\begin{array}{l}\text { 2th power } \\
\text { enterprises }\end{array}$ & $\begin{array}{l}\text { 3th power } \\
\text { enterprises }\end{array}$ \\
\hline volume of $\mathrm{CO}_{2}$ captured, $\mathrm{t} / \mathrm{Mwh}$ & 0 & 0.951 & 0.859 \\
\hline volume of $\mathrm{CO}_{2}$ emission, $\mathrm{t} / \mathrm{Mwh}$ & 0.797 & 0.106 & 0.095 \\
\hline $\begin{array}{l}\text { Operating cost without subsidy, } \\
\text { RMB/kwh }\end{array}$ & 0.279 & 0.409 & 0.364 \\
\hline $\begin{array}{l}\text { Government subsidies, } \mathrm{RMB} / \\
\mathrm{tCO}_{2}\end{array}$ & 0 & 202 & 202 \\
\hline $\begin{array}{l}\text { Operating cost with } \\
\text { subsidy, RMB/kwh }\end{array}$ & 0.279 & 0.217 & 0.190 \\
\hline
\end{tabular}

With double positive conditions of the income from CDM projects and government subsidies for CCI in clean low-carbon mechanism, the unit operating costsof the second and the third type of electric power enterpriseswill greatly obviously reduce in A city. Their reduced value less $77.78 \%$, $68.1 \%$ than the first kind of electric power enterprises' costs. In this case, the CCI, such as electric power industry, must be structural changed, so than more and more coal enterprises will certainly join to clean mechanisms in lowcarbon technologies. Especially, CCI will turn to circular economy management mode of all-round development directionswith clean mechanisms in A city.

\section{Coming into being the data of Carbon labels}

Using the clean development mechanisms, the electric power enterprises with CCS or IGCC in A city may enjoy the income of CDM projects and government subsidies. At the same time, their downstream consumers (industrial, residents) also get benefits. First of all, because the electric power enterpriseswith low-carbon technologies reduce a 
large amount of GHG emissions, it improves the quality of living environment forresidents in $\mathrm{A}$ city.The second, the consumers in A city will pay lower electric consumption tax than ever for choosing different types power products with CL fromthe different enterprises. Because downstream products' consumers in A city may view and analyze the $\mathrm{CL}$ on the power products from different types of enterprises, they are able to make rational choices to $\mathrm{CCI}$ products with $\mathrm{CL}$ in low-carbon technologies, which is shown in Table8.

Table 8. The data from the three kinds of the CL

\begin{tabular}{cc}
\hline \multicolumn{2}{c}{ XX1 electric power enterprise (1th type CL) } \\
\hline Production mode & tradition coal-electric power enterprises of \\
& coal supercritical boilers without CCS \\
volume of $\mathrm{CO}_{2-\mathrm{e}}$ emission, $\mathrm{t} / \mathrm{Mwh}$ & 0.797 \\
\hline
\end{tabular}

\begin{tabular}{cc}
\hline \multicolumn{2}{c}{ XX2 electric power enterprise (2th type CL) } \\
\hline Production mode & tradition coal-electric power enterprises of \\
& coal supercritical boilers with CCS \\
volume of $\mathrm{CO}_{2-\mathrm{e}}$ emission, $\mathrm{t} / \mathrm{Mwh}$ & 0.106 \\
\hline & \\
\hline $\mathrm{XX} 3$ electric power enterprise (3th type CL) \\
\hline Production mode & coal-electric power enterprises with CCS and \\
& IGCC technologies in CCI \\
volume of $\mathrm{CO}_{2-\mathrm{e}}$ emission, $\mathrm{t} / \mathrm{Mwh}$ & 0.095 \\
\hline
\end{tabular}

Above three groups of different power CL data,consumers of CCI products can see the second and the third type products have lower carbon emissions in the process of production. If there is the carbon tax to the consumers of CCI productsin A city, the consumers of CCI products clearly know that how much he will pay consumption tax according to the above three different CL, which is shown in Table9.

Table 9.The carbon tax of the three kinds of the CL

\begin{tabular}{lccc}
\hline The choosed objects by consumers & 1th product & 2th product & 3th product \\
\hline Consumption tax rate, $\mathrm{RMB} / \mathrm{tCO}_{2}$ & 10.00 & 10.00 & 10.00 \\
volume of $\mathrm{CO}_{2}$ emission, $\mathrm{t} / \mathrm{Mwh}$ & 0.797 & 0.106 & 0.095 \\
Unit consumption tax, $\mathrm{RMB} / \mathrm{kwh}$ & 0.00797 & 0.00106 & 0.00095 \\
\hline
\end{tabular}

Contrasting the different $\mathrm{CL}$ on the products and consumption tax, consumers will account out the payment for each $100 \mathrm{KWH}$ : the first kind of consumption patterns need to pay RMB0.8 for carbon tax, the second and the third type of consumption patterns to respectively pay RMB 0.11 and RMB 0.09 for carbon tax. If there is the same price in A city, consumers' choiceswill be obvious.

\section{CONCLUSION}

At first,this paper redefines the carbon footprint and carbon labels, and analysis the application significance of carbon labels of products under the background of the development of low-carbon economy. Especially, the carbon labels of the coal chemical products have the real value to reduce the carbon footprint in coal chemical industry in China. The paper uses the instance to study the data sources of carbon labels on the coal chemical products based on establishing the conceptual model of carbon labelsby the contrast three kinds of electric power products in CCI, which are the technologies of supercritical boiler without CCS, technologies of supercritical boiler with CCS and adopting technologies of CCS and IGCC to power generation in CCI including the subsystem of coal mining, the subsystem of coal logistics, the subsystem of coal chemical processing, and so on. 
Therefore,the paper is not only providing new ideas for the sustainable development of coal chemical industry in China,but also establishing the carbon labels mechanism of chemical products under the low carbon consumption.

\section{ACKNOWLEDGMENT}

The paper is one of research achievements of Social Planning Project: (1) "2016 scientific research projects of colleges and universities of Hebei Province (Department of Province Education)";(2) "2015 annual field publishing fund projects of Langfang Teachers University, Hebei"; (3) "2016 major subject in the humanities and social sciences research project of Department of Education of Hebei Province".

\section{REFERENCES}

[1] BSI,PAS 2050: 2008 Specification for the Assessment of the LifeCycle Greenhouse Gas Emissions of Goods and Services[S].2008,1-25.

[2] Gossling S, Garrod B,et al. Food management in tourism: Reducing tourism's "carbon footprint'[J].Tourism Management,2011,32(3):534543.

[3] Bing Zhang, Yan He.Research of consumer behavior in carbon label of food [J].East China Economic Management, 2013, 27(4):41-46.

[4]Jinkai Li, Jin Zhang,Research on the Total Factor Productivity and Decomposition of Chinese Coastal Marine Economy: Based on DEA-Malmquist Index[J]. Journal of Coastal Research, 2015(73):283289.

[5]Laura Castro-Santos, Vicente Diaz-Casas. Cost Comparison of Three Floating Offshore Wind Platforms[J]. Journal of Coastal Research, 2015, 31 (5): 1217-1221.

[6]Marcos R. Rossi-Santos. Oil Industry and Noise Pollution in the Humpback Whale (Megaptera novaeangliae) Soundscape Ecology of the Southwestern Atlantic Breeding Ground[J]. Journal of Coastal Research, 2015, 31 (3): 184-195.

[7] Hans-Jürgen Schmidt. Carbon footprint, labels and life cycle assessment [J]. In J Life Cycle Assess, 2009(14):6-9.

[8] Baddeley S, Cheng P, Wolfe R. Trade policy implications of carbon labels on food [J].Estey Centre Journal of International Law and Trade Policy,2012, 13(1): 59-93.

[9] Jacobs B, Subramanian R. The impacts of sharing responsibility for product recovery across the supply chain $[\mathrm{J}]$. Production and Operations Management, 2012, 21(1): 85-100.
[10] Li Guo, Qiang Cui.New tools of low carbon lifecarbon label[J]. Ecological Economy,2011(7):8184.

[11] Bishan Wu, Haibin Liu. Study on Measurement Problems of External Cost of Coal Railway Transportation Railway Transportation[J].Highlights of Science paper Online in China,2014(5):989-992.

[12] Metz B, Davidson O. EPCC Special Report on Carbon Dioxide Capture and Storage Prepared by Working Group III of the Intergovernmental Panel on Climate Change [M].Cambridge University Press, 2005

[13] Green Coal Electric co., LTD. The challenge of global climate changing-- $\mathrm{CO}_{2}$ CCS[M].Beijing:China Water Power Press, 2008.

[14] Xuedong Zheng, Songtao Zhang. Technology of $\mathrm{CO}_{2}$ gathering in coal-fired power plant and economicanalysis[J]. Shanghai Petrochemical,2011(05):19-23.

[15] Qingguo Mao, Guifeng Cheng. Coal mining area coal bed methane power generation scheme analysis in China[J].China Coalbed Methane,2009(10):32-34.

[16] Bishan Wu. Research on the carbon footprint measurement and thecontrol mechanism for Coal Chemical IndustryChain[D].Beijing:China University of Mining \& Technology, 2015. 